\title{
4. 魚類の対光行動とその生理
}

\author{
4-1. 魚類の対光行動 \\ 井上実*
}

\section{I. 粕 言}

集魚灯漁業は水中動物（以下，魚という）の光に集まる性質を利用したものであるが，魚には光に集变る ものと，集まらないものがあり，本来集まるはずの魚も，その時の環境条件に影響されて集まらないといら 問題もある。さらに，集まった魚を光域に長く滞留させること，その離散を防ぐことなど考慮すべき問題が 多い。また，魚はなぜ光に集まるという基本問題についても，いくつかの見解が示されている。たとえば， 魚の好奇心説，好適照度説，摂慨集群説，走光性に基つく強制運動説などである。

ここでは魚の対光行動を「走光性と魚類」「走光性のしくみ」「走光性と照度」「走光性と群集」「走光性と 漛境」の5つの項目に分けて調べだ。

\section{II. 走光性と魚類}

走光性 Phototaxis とは動物が光刺激に定位し，運動する行動をいい，光源に向って定位，渾動寸ること を「正の走光性」，光源から遠ざかるのを「䝿の走光性」といら。

な妨，走光性は研究者により越光性 Phototropism とも乎ばれている。この混用について数人の学者

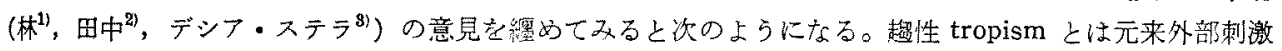
に対する棺物体各器官個有の軸定位をい5が，LOEB が動物の外部刺激に対する反応们動毛植物のそれと， すなわち䞶性反応と同一現象であるとい5見解を示し，動物の方向透動も trōpism という言葉で現わした

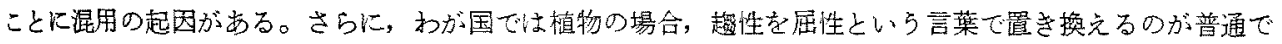

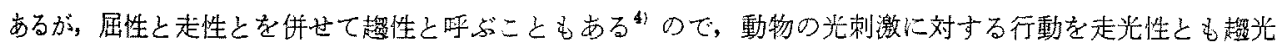
性ともいら原因を強めている。本交中では走光性といら言葉を統一的に用いるが，引用した文献中その藷者

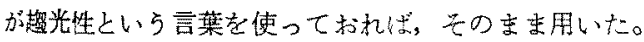

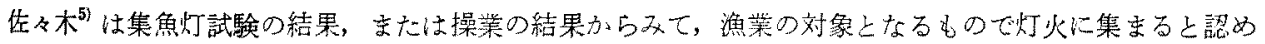
られるものに, サンマ, マイワシ，カタクチイワシ, ウルメイワシ，ムロアジ,マアジ,サバ, コノシロ， 小ニシン, イカ, スケトウダラ, カッオ, トビウオ, ユチ, イカナゴ, サッパ, クルマエビ, カ二などを挙

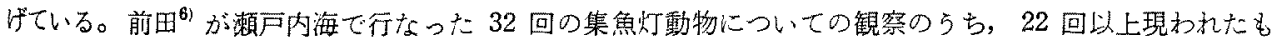

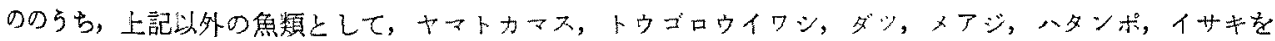
挙け゚ている。井上7はマダロカッ才類の $600 \mathrm{~W}$ 昼光色電灯に対する走光性を調べ, クロメジは正の，八ガ シオ・ソウダカッオは顀の走光性を示をことをみな゙。

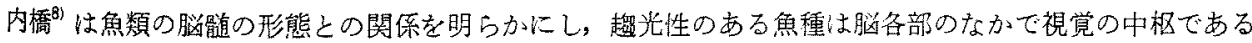
Lobus cpticus（視葉）が最も大きく，ての側面に陷凹部 (Fovea) を形成するか，されにそれが発達して Lateralen Einschnürung を形成することを指摘した。そしてこのよらな Lobus opticusをむつ種は全

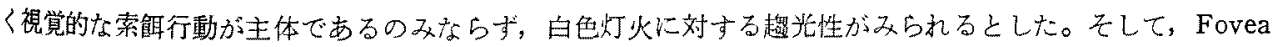
または Lateralen Einschürung を有する種のリストにより，趨光性之の関係を示した。その表を集魚灯漁 業の対象になる魚種を中心に要約すると Table 1 のよになる。

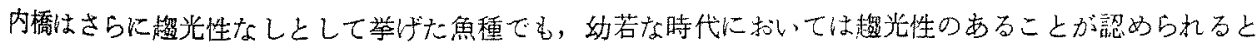

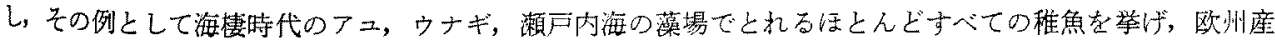
のタラ (Dannevig, 1932) の幼魚もその例であるとしている。

\footnotetext{
*東京水産大学 (Tokyo University of Fisheries, Minato-ku, Tokyo)
} 
Table 1. Form of Lobus opticus and mutual relation of phototaxis.

\begin{tabular}{|c|c|c|}
\hline \multicolumn{3}{|c|}{ Degree of phototaxis to white light } \\
\hline \multicolumn{2}{|l|}{ Intence } & Weak or none \\
\hline It has "Fovea" & It has "Lateralen Einschnürung & $\begin{array}{l}\text { No Fovea and } \\
\text { Lateralen Einschnürung }\end{array}$ \\
\hline Species name (Japanese name) & Species name (Japanese name) & Species name (Japanese name) \\
\hline $\begin{array}{l}\text { Engrauls japonica } \\
\text { (Katakuchiiwashi) }\end{array}$ & $\begin{array}{l}\text { Etrumeus mieropus } \\
\text { (Urumeiwashi) }\end{array}$ & $\begin{array}{l}\text { Mugil cephulus } \\
\text { (Bosa) }\end{array}$ \\
\hline $\begin{array}{l}\text { Cololabis saira } \\
\text { (Sanma) }\end{array}$ & $\begin{array}{l}\text { Sardinops melanosticta } \\
\text { (Maiwashi) }\end{array}$ & $\begin{array}{l}\text { Coryphaena hippurus } \\
\text { (Shira) }\end{array}$ \\
\hline $\begin{array}{l}\text { Scomber japōnicas } \\
\quad(\text { Masaba })\end{array}$ & $\begin{array}{l}\text { Harengula zunasi } \\
\text { (Sappa) }\end{array}$ & $\begin{array}{l}\text { Seriola quinquerdiata } \\
\quad \text { (Buri) }\end{array}$ \\
\hline $\begin{array}{l}\text { Trachurus japonica } \\
\text { (Maa!) }\end{array}$ & $\begin{array}{l}\text { Hemiramphus sajori } \\
\text { (Sayori) }\end{array}$ & $\begin{array}{l}\text { Lateolabrax japonicus } \\
\text { (Suzuki) }\end{array}$ \\
\hline $\begin{array}{l}\text { Leiognathus nuchalis } \\
\quad \text { (Hiragi) }\end{array}$ & $\begin{array}{c}\text { Sphyraena japonica } \\
\text { (Yamatokamasu) }\end{array}$ & $\begin{array}{l}\text { Chrysophrys major } \\
\text { (Madai) }\end{array}$ \\
\hline & & Other 30 species \\
\hline
\end{tabular}

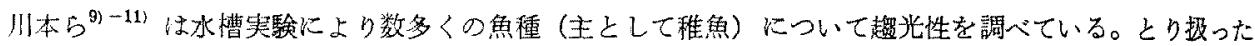

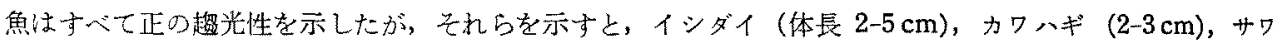
ラ $(2-4 \mathrm{~cm})$, トラフグ $(8 \mathrm{~cm})$, ヤマトカマス $(8-9 \mathrm{~cm})$, マ术 $(3-5 \mathrm{~cm})$, メジ $(2.5-4.5 \mathrm{~cm})$, トラ フグ $(1.6-2.0 \mathrm{~cm})$ ，メダカ $(2.5-2.6 \mathrm{~cm})$ ，八タンポ $(1.8-2.4 \mathrm{~cm})$, マアジ $(16.2 \mathrm{~cm})$ である。

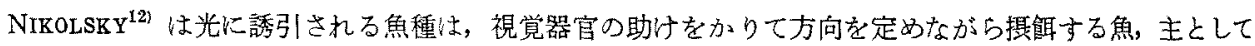
可視性プランクトン食魚類であるとした。

魚種による走光性の強弱を定量的に調べることは興味深いが，走光性上集魚率は薏うもので，魚が本来持 っている性質が走光性であり，光を点じた時に現われる現象が集魚率であるとしている。BREDER ${ }^{13)}$ は23

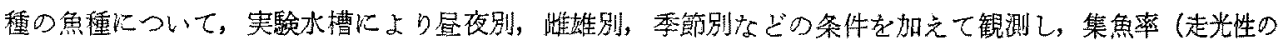
强弱)を燢的に示した。

III. 走光性のしくみ

走性 taxis とは外部からの刺激に詨し，動物がその体軸を刺激の方向にして常に一定の関係を保ちなが ら渾動する性筫であるから，走光性 Phototaxis む光源の方向とある関係を保つて渾動する性質である。し かし，動物の光に対する反応がすべて光源と関俰があるとはいえず，刺激の力向と無関係な運動を Photokinesis (光活動性) といら。魚の光に対する反灾の多くは走性であるが，負の走光性にはPhotokinesis が ふく狆ていることをWOODHEAD ${ }^{14)}$ 小指摘している。

走光性には制激相称性, 保目標性, 保留性の3つの型があり, 刺激相称性は两眼の光受容面の光の量の盖 が，保目標性，保留性は一服の光受容面の部分的な受光量の差が刺激となる。LōEB は走性の研究の先駆者 であるが，彼は走光性を刺激相称性で説明し，さらに強制運動説を提唱し，光エネルギーが動物の光受容器 内に光化学的变化を起し，その結果，結局動物の社動器官の活動に变化を及法して强制的に動物を光源に向 つて，または光源を遠去かるよらに仕间けるのであるとしている。

VERHEIJEH ${ }^{15,16)}$ は LOEB の強制運動説を発展させ，剌激相称性，保目嫩性，保留性江基づ走性によつ

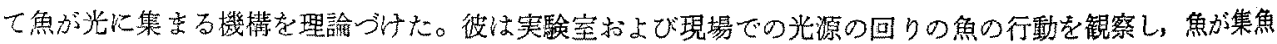
忊に集まるのは夜問昆虫が光源へ集まることに著しく類似しているとし，それは光源の回りの異常な明るさ

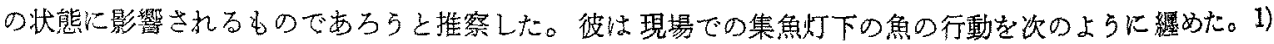
表面近くを泳ぐ，2）汪とんど勳きがなく垂直になる，3）光源に掅触するか，笑如ランプに荒々しく突進す る，4）水面には水る，水面に浮び出る，5）馬てい型に体を曲げる，6）麻瘦状態になり，たる網でる抄克 
る。このよらな観察から, 彼は光源下の魚の一般的な行動は方向感覚喪失 (disorientation) の状態にあるこ とを指摘した。

彼は結論として，魚は自然光線に対しては中枢神経系による自動制御機構が正常に僠き，照度選択を行な らが，人工光線に対しては自然光とくらべ刺激の異常なために自動制御機構が惑わされ，魚が本来進さコ一 スからそれる原因となり，一方，強制的に走光性が働く結果，人工線に誘引されるとしている。

さらに，このような理諭に基つきき，漁場に批てて効果的に魚を誘引する条件として，1）自然光（月光） が弱いこと，2）水が透明なこと，3）水深は海底からの反射を消失させるほど十分に深いことを举げている。 BLARTER \& PARRISH ${ }^{17)}$ は彼等の実験のらち，若いニシンや，ニシン類の sprat はある時間水中集魚灯の 囲りをぐるぐる回つているが，それは魚の片側の眼だけが光に刺激された結果であると考克，VERHEIJEN の理菕があてはまるとした。しかしタラ類の whiting は光源からある距離の好適照度域に集つている上 らであり，方向感覚或失の状態ではないとした。

\section{IV. 走光性と照度}

魚が光に集まり，また灯下に滞留する原因の説明の一つとして，好適照度 (preferred light intensity)， 適正照度 (optimum light intensity) 説がある。いずれも魚には好む明るさがあり，その明るさの層に集 るといらもので, 魚の日周垂直行動も好適照度説で説明する研究者もいるが，VERHEIJEN の上うに自然光 への反応と，人工光線への反応恃異なるものであるといら説もある。

好適照度が日中と夜間とで同じかどうか調べた BLAXTER \& PARRISH ${ }^{17)}$ の実騟がある。ある場合は日中 の whiting は夜間, 人工光線に集つた 0.06-0.22 Lux の明るさとほぼ同様の明るさの $0.17 \mathrm{Lux}$ の水域を 泳いでいたが，ある場合は日中と夜間の遊泳層の明るさは同じでなかつた。後者の場合について彼等は， whiting は夜間は低い照度に順俯するが，日中はより高い照度に順応し，この好適照度の違いは日中之夜間 とで調節を必要とするほど大きくないかあるいはとの調節は魚の垂直䔟動化伴つて行なわれるむのである らとした。

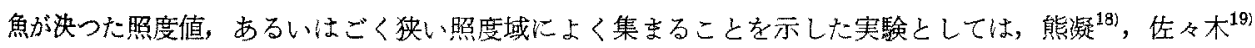

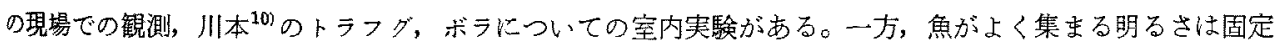
的なむのではなく，光源の大きさ，環境の条件に伴つて変る可咬的なものであるといらカタクチイワシ， サ

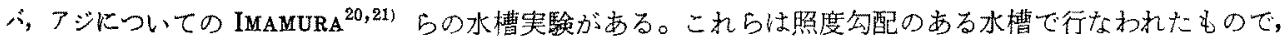
どの照度箩囲でその行動が制約されるか, 变化するがみている。この他, 照度勾配のある水槽内での寒験 蛥く, WOODHEAD ${ }^{14)}$ は minow について, WOODHEAD \& WOODHEAD ${ }^{22)}$ はニシンの稚魚について, GIBSON \& KEENLEYSIDE2) は若い大西洋産サヶ (Salmo salar) とカワマス (Salvelinus fontinalis) について観 察している。一般に办槽内では魚のよく集をる照度範用は広いよらである。

好適照度説の一つの条件は，魚はその好む照度域に長く滞留することであるが，今村年のマアジについて の锶察によれば，光源下の明るい部分に停止するものはなく，光源に接近して，票た，暗い方に向つて去り， 再びある時間経過して光源に向つて集まるので, 光源下の魚は常に入れ代つているという。黑木・中馬 ${ }^{25}$ は

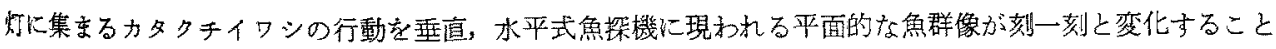
らか, 集魚灯に集まつたイワシ群は相当な遊泳速度で離合集散し, 活発な運動を行なつているものと推察し た。

三浦 ${ }^{201}$ はサンママ対する水上灯，水中灯の試験を行ない，水上灯ではサンマは光源直下約 $2 \mathrm{~m}$ のとこ を中心滵集し，相当長時間灯についたが，水中灯では水上灯上り光源が小さいにもかかからず，サンマ 柱光源を遠巻きにして遊泳し，灯具のわずかな摇れにも散り易く短時間で火から離れることをみた。このこ と恃光源が水上か水中かによつてサンマに対する最適刺激值が異なることを意味する。

\section{v. 走光性と群集}

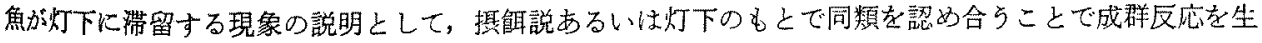
じその結果，集魯効果が高まるといら成群説もあり，生態乐あるいは群集としての対光行動の考察が必要 
になる。

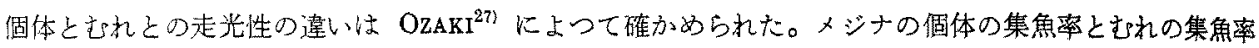
の違いなどから，魚がもれを形成している場合には：こ杞らの封光行動を単なる個体の集合として考えるの は告険で，㧈の場合はむれとしての特性を現わすことを考慮しなければならないとした。

䒺飷説は前田の研究によつて代表されるが，同様の見解を示寸研究は多い。前田は魚が光に集まること， 灯火に留まるこ上の原因として光と眲の 2 つ原因を举げ，この両者唍全に分離して考えることはできな

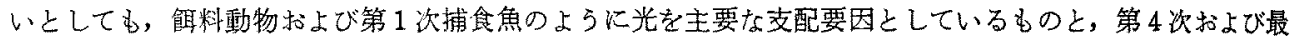
終捕食魚のよらに慨料を支配要因としているものとがあるとした。そして，その間には(光が飭料よりも強

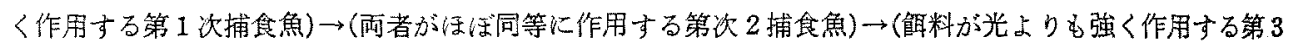
次捕食魚) の諎段階が存在していることを論してている。彼は実験の結論として，光に集まる原因を走光性の 他，生物の相互関係を考え，後者については最も重要なのは食飭関係であると断定している。

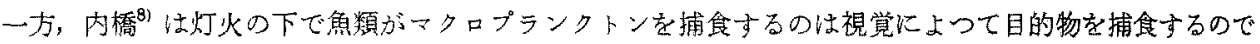

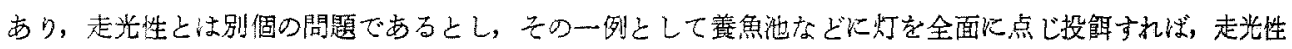

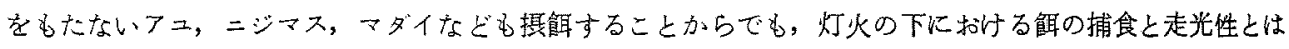
別のむのであるとしている。

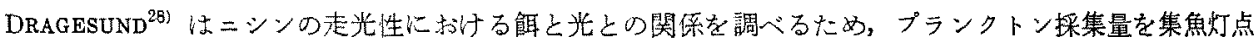
灯前と点灯中とで比較した。ニシンは走光性は弱いが，たまたまニシンが集合して光源い向つて上昇した場 合について2回の観测を行なつた。その結果忙 Calanus finmarchicus を主とする動物プランタトンは点 灯中に多く集まるとはいえず，彼はニシンは能を食べるために光に集まるとはいえないとしている。

集黄灯の研究とは別に，視覚に上る成群のためには最低どの程度の明るさが必要かといら視覚生理学的な

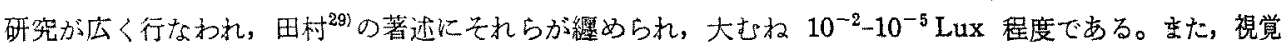
に上る索䭒に必要な最低照度は JONES ${ }^{309}$ は $0.007 \pm 0.00007 \mathrm{~m} \cdot \mathrm{c}$ と，HUNTER ${ }^{31)}$ は $6 \times 10^{-5}$ Lux として いる。したがつて，成群，索期に必要な最低の照度は魚種によつて違らが $10^{-2}-10^{-5}$ Lux 程度であるう。 一方，集魚灯下に魚が出現する最低の照度域多多くの実娩の結果から $10^{-2} \mathrm{Lux}$ あるいはそれ以下であると みなされる。この照度域の一致があつたとしても，直ちに㑭はむれれ作りのため灯下に集まるとはいえない。 しかし，走光性の强いとみなジるイワシ，アジ，サバ，サンマ，イカナゴなどは成群性の強い焦でるある からこれらの魚にされ作りの要求が絶えず働いているとすれば，夜間視覚が失われ，むれが分散していて

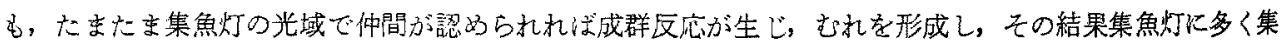
まることになるら。

\section{VI. 走光性と檌境}

灯火に一旦集まつた魚群が灯火から離散する現象，下尿に集末つても上算をで浖上しない現象，前夜灯火 に集つた魚が翌夜は存在しても集まらない現象，また季節別の灯付きの良不良の現象などがある。その大き な原因として環境の变化が挙げられる。環境には魚にとつて外部環境と内部環境とがあるが，ここでは外部 環境として水温, 潮流, 月光について，内部環境として魚の成長段階, 雌雄別, 胃内容度, 造について調べ，別に光刺激に対する馿れ，学習効果も考察した。

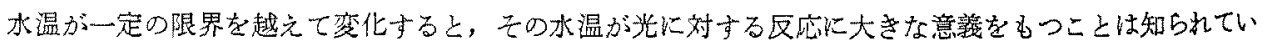
る。一般には高温になると走光性は弱くなり，低温になると強くなる。あるいい高温になると走光性は造に 反走光性に転換することもあり、このことは塩分濃度についてもいわれる。

相沢 ${ }^{32)}$ ，今村 ${ }^{33)}$ はサンマについて水温と灯付きの関係を調へ，NIKONOROV ${ }^{34)}$ は Caspian kilka（力夕ク

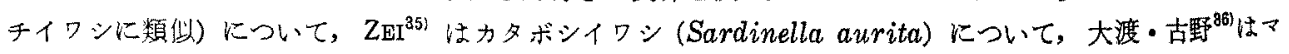

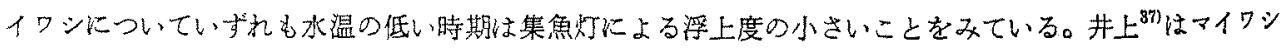
について同椂の観察を行なつたが，浮上度の大小は水温などの燢境条件の他に，魚の成長段階も考虑すべさ であるとしている。 
潮流と灯火に集まる魚群の状態では，はつきりした定性的な関係は見出乙得ないが，関俰が深いことは。

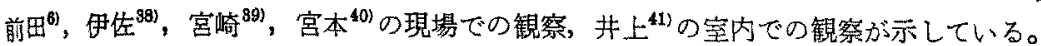

集魚灯漁業に淤る月光の影響として，川本 ${ }^{11}$ らはマフジについての野外実験から一般的には月光が明る 〈なれ代集魚効果は劣るであるうが，月夜でも光源が大き计机ばある程度魚を集め得るだるらと推定してい る。しかし、サンマの漁獲試験の報告は一概にに月明時には漁獲は少ないとはいい切れないとしている。前 田纹はメジナを用いた水槽実験で，月光の影響を弱い光に順応した状態とみている。

成長段階によつて走光性は変化し，奻魚は成魚より走光性法著しいことは著明である。山田 ${ }^{43)}$ はマアジに かて上記の現象を述べ，WOODHEAD ${ }^{44)}$ はブラウントラウトニジマス，大西洋産サヶ (Salmo salar) は 稚魚の初期は光に対しよく正の反応を，後期汇は反応は鏈くなり，さらに成長に伴い負の走光反応を示すと した。

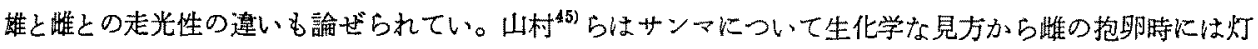
付きが覀くなることを述べ，今村 ${ }^{837}$ る同様な現象がマイワンにみられることを指摘している。BREDER ${ }^{189}$ は カダヤシ類の Gambusia sp. メダカ類の Cyprinodon baconi, ウルメイワシ科の Jenkensia sp. の雄と集 との違いを水槽実験によつて調べ，季節によつて遠いがあることを指摘した。

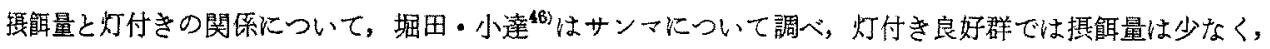
灯付き不良群では掑慨量が多い傾向があることを見出した。WOOBHEAD ${ }^{14)} の$ minow の行動の観察によれ

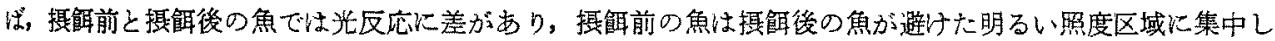
た。

また，灯火による魚群の浮上度はうきぶくろの構造と関保のあることが考えられる。BLAXTER \& PARRISH ${ }^{17)}$ は herring, sprat (有管嘌魚) は whiting (無管䇺魚) 上り水王变化への耐容度が大きいが, それが集魚灯に上る浮上度の堡いに関係があるとしている。

このような外部的内部的環境の影響は魚の灯付きの良不良方るいは離散の原因となるが，さらに長時間の

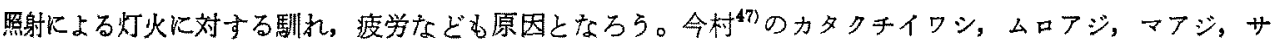
バついての室内実験からは，1時間程度の照射では魚に馿れや疲労は生じないといら結論が得られた。川 本 ${ }^{10)}$ らの室内実験からは魚種に上つて違い,メジナの上らに本来光に集万らとする本性をるつ魚は馿れや疲 学はみられないが，サワラの上うな走光性の弱い魚にはその影響が現われるとした。岡融のメダか,ドジ ウ，スジェビ，フナに上る水槽実験から，光刺激が上限の閾值に達すると，集角効果が失われることがわか つた。井上"注海獲の記録からアジサバについて光刺激の時間と光の誘引効果の関係を調へ， 3 時間以上の 照射からマイナスの影響が出ることを見出した。

奵下に集つた魚群の離散に関しては外敵の出現は極めて大きい要素であるが，この面の研究は少ない。前 田( は集魚灯動物の群集生態学的研究のなかで総括的に論じ, BLAXTER \& PARRISH ${ }^{17)}$ はニシン類の sprat とその外敬であるサバの関係を論じている。

光に対して本来葉るべき魚が集まらない原因の一つとして，光と紌による恐怖と結びつけた学習に起因す

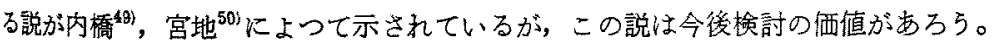

\section{文献}

1) 林 泉：動物趝性学, p. 41-43, 羡観堂, 東京 (1936).

2）田中良久: 動物心理学, p. 119, 共立出版, 東京 (1956).

3）デシア・ステラ：動物の行勘（日高敏隆訳）， p. 79，岩波書店，東京 (1962).

4) 理化学辞典, p. 777, 岩波書店, 東京 (1965).

5) 在々木忠義：集魚灯，p.7,1デア書院，東京 (1953).

6) 前田 弘: 魚類学雑誌, 1, 349-360 (1951).

7) 井上元男他 4 名： 東海大学紀要，41，53-58 (1969).

8）内橋 潔：日本海区水研究報告， 2，1-162 (1953).

9）川本誩之他 3 名：水産研究会報，3，153-188 (1950). 
10）川本信之は加：水㦃研究会報，4，263-291（1952).

11）川本信之他 4 名：水應研究会報，5，101-132（1953）.

12) G. V. Nikolsky: The Ecology of Fishes, p. 44, Academic press (1963).

13) C. M. Breder, JR: Bull. Amer. Mus. Nat. Hist., 117(70), 397-481 (1959).

14) P. M. J. WoodeEad: J. Exp. Biol., 33, 257-270 (1956).

15) F. J. VerheiJen: Arch. Néerl. Zool, 13, 1-107 (1958).

16) F. J. VerheiJen: Modern Fishing Geas of the wolrd, 1, 548-549 (1959).

17) J. H. S. Blaxter \& B. B. PARrish: Mar. Res. 2, 1-21 (1958).

18）熊凝武晴：水産科学 (水産科学社)，1，14-17 (1959)。

19）值夕末忠楳：日本機械学会誌，52(372)，443 449 (1949).

20) Y. IMaMura \& S. TAKeuchI: J. Tokyo Univ. Fish., 46, 133 148 (1960).

21) Y. IMAMURa: J. Tokyo Univ. Fish., 45, 186-193 (1959).

22) P. M. J. Woodhead \& A. D. Woodhead: Nature, 176, 349-350 (1955).

23) R. J. Gibson \& M. H. A KeEnleyside: J. Fish. Res. Bd. Canada, 23, 1007-1024 (1966).

24) 今村 豊: 5み, 日仏海洋学会誌, 6, 136-147 (1968).

25）黑木敏郎・中馬三干雄：麇児島大学水産学部紀裂，6，77-81 (1958).

26) 三浦鉄雄：北大水産学学研究策報 1, 142-150 (1951).

27) H. Ozaki: Rep. Fac. Fish., Prefecture Univ. Mie 1, 56-66 (1951).

28) O. Dragesund: J. du. Cons., 23, 213-227 (1958).

29)田村 保: 魚類生理 (川本信之編), 視党, p, 426-428, 恒星社厚生閣, 東京 (1955).

30) F. R. H. JoNES: J. Exp. Biol., 33, 271-281 (1956).

31) J. R. Hunter: J. Fish. Res. Bd. Canada., 25, 393-407 (1968).

32) 相沢素雄: 東北海区水研研究報告, 23, 85-92 (1963).

33) 今村 豊: 火光利用漁業の研究, プリント。

34) I. V. Nikonnrov: Modern Fishing Gear of the World, 1, 559-566 (1967).

35) M. ZEI: FAO Fisheries Reports, 62, 469-475 (1967).

36) 大渡 敦・古野清賴：本誌，19，1072-1076 (1954).

37) 井上 実: 本誌, 29, 925-929 (1963).

38) 伊佳良信：本誌，27，493-500 (1961).

39）富䯚千器：本誌，16，235-238 (1950)

40) 宮本秀明: 定置網漁論, p. 215-216, 河出彗房, 果京 (1954).

41) 井上実：5み，日仏激洋学会誌，8，69-77(1970).

42) H. MAEDA: 本誌, 22, 1-4 (1956).

43）山目鉄男：対馬暖流開発調查報告慧（水産庁），145-176（1958），

44) P. M. J. Woodhead: J. Exp. Biol., 34, 402-411 (1957).

45）山村弥太郎・武藤清一郎: 東北海区我研研究報告, 21, 57-62 (1962),

46）堀田秀之一小達和子：東北海区水研研究報告，7，60-69（1956).

47) 今村 豊: うみ，日仏海洋学会誌，6、17-43 (1968).

48) 阔正 雄: 本誌, 16, 233-234 (1950),

49)内榙 潔：対馬暖流開発調查，第 4 回シンポジウム発表諭文，259-260 (1956).

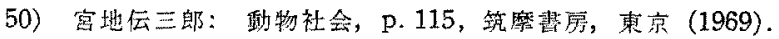

